\title{
ПРОБЛЕМА СЛУЖБИ ЖІНОК У ЗБРОЙНИХ СИЛАХ У БРИТАНСЬКОМУ ПУБЛІЧНОМУ ДИСКУРСІ 1939-1945 РР. (НА МАТЕРІАЛАХ ПЕРІОДИЧНИХ ВИДАНЬ)
}

Анотація: Метою статті є аналіз особливостей сприйняття британським суспільством y 1939-1945 рр. служби жінок у збройних силах як явища. Авторка доходить висновку, що у британській періодиці зазначеного періоду була оприлюднена низка матеріалів, в яких містилася оцінка широкого спектру заходів, пов'язаних із залученням британок до служби у війську, порушувалися питання про засади, на яких могли служити жінки тощо. Мусимо констатувати, що у представлених публікащіях містилася низка критичних висловлювань щодо жіночої служби, особливо це стосувалося можливості виконання ними бойових ролей. Вельми значна увага у контексті обговорення служби британок приділялася не питанням, пов'язаним 3 їхньою фаховістю, а зовнішньому вигляду, особливостям форми, яка, на думку деяких, не була «жіночною», проблемам, які потенційно можуть виникнути через те, що успіхи британок на службі у збройних силах стануть перешкодою майбутньому заміжжю, адже самодостатні жінки навряд чи будуть покірними тощо.

Ключові слова: жінки, збройні сили, Друга світова війна, Велика Британія, жіночі допоміжні організації, публічний дискурс

Друга світова війна стала настільки масштабним збройним конфліктом в історії людства, що багато країн, які брали участь у ній, були змушені переглянути свою політику щодо залучення жінок до служби в армії. Велика Британія, попри свою доволі консервативну репутацію у сфері гендерної політики, офіційно почала залучати жінок до служби у допоміжних організаціях при війську ще у роки Першої світової війни. У 19391945 рр. вона суттєво розширила масштаби залучення жінок до служби у збройних силах, а також список доступних їм посад. Подібні заходи були неоднозначно сприйняті суспільством, і самим жінкам не раз доводилося потерпати від різного штибу упереджень, пов'язаних з їх присутністю у війську. Особливо соціум непокоїла можливість допущення жінок до бойових посад у збройних силах. І хоча впродовж війни уряд так і не зняв заборону на використання жінками летальної зброї та виконання ними бойових ролей, подібна вірогідність активно обговорювалася у публічному дискурсі, особливо у перші роки війни, на тлі перемог противника. Непокоїли суспільство й інші дотичні проблеми, зокрема вигляд жінок у військовій формі, ймовірна втрата ними жіночності внаслідок вступу на службу тощо.

\footnotetext{
" Залєток Наталія Валеріївна - кандидатка історичних наук, завідувачка відділу архівознавства Українського науково-дослідного інституту архівної справи та документознавства (Київ, Україна);

ORCID: https://orcid.org/0000-0002-5319-3876; e-mail: nataliazaletok@gmail.com
} 
Метою статті є аналіз особливостей сприйняття британським суспільством у 19391945 рр. служби жінок у збройних силах як явища. Джерельною базою дослідження $є$ матеріали британських періодичних газет.

Публікація матеріалів, присвячених службі жінок у збройних силах Великої Британії та інших країн розпочалася практично від самого початку війни. У 1939 р. здебільшого публікували матеріали про досвід жительок інших держав, проте маловірогідно, що метою їх оприлюднення було тільки інформування про справи за кордоном. До того ж, заголовки таких статей не відразу давали змогу читачеві зрозуміти, про яку країну йдеться. Приміром, у статті «Жінки беруться за зброю» («Women Take Up Arms») йшлося про те, що польські жінки, заохочені їхнім урядом, зі зброєю у руках бороняться від нацистських загарбників. А Велика Британія це підтримує 1 .

Поряд 3 цим періодично з'являлися статті про те, наскільки змінилися жіночі ролі 3 початком війни. Зокрема, цьому присвячено замітку «Ключові жіночі досягнення у війні в 1939 р.», де наголошено на тому, що 1939 р. ознаменувався багатьма справами, що були зроблені жінками вперше. Серед іншого у ній згадувалися британки, які очолили ключові жіночі служби - Жіночі допоміжні повітряні сили (Дж. Трефузіс Форбс) і Допоміжну територіальну службу (Х. Гвін-Вон) ${ }^{2}$. Вбачаємо у таких публікаціях, серед іншого, і приховану мету - підготувати британське суспільство до чергового розширення кола суспільних ролей жінок у роки війни, включно з тими, які передбачали безпосередню участь у боях зі зброєю в руках. Адже у перші роки війни ситуація на фронтах складалася не найкращим чином для Великої Британії, й у владних колах порушувалося питання про ймовірне допущення жінок до виконання бойових ролей, як це було в СРСР і деяких інших країнах 3 .

Великою проблемою для тодішнього соціуму вважалося питання зовнішності жінок на службі, яке так чи інакше буде виринати на шпальтах газет впродовж всієї тривалості збройного конфлікту. Мусимо констатувати, що такі матеріали були просякнуті сексизмом і лукізмом. Наприклад, досить дивна, на наш погляд, стаття «Між тобою і мною. Позбавте нас від культу охайності: жінки-солдати сьогодні більш виховані» («Twixt you and me. Save us from the cult of tidiness: women soldiers more genteel to-day») є серед них. Ïї автор опублікував матеріал під псевдонімом. Більшу частину тексту він іронізує над чоловіками, які приділяють увагу охайності, приміром голяться щодня (на відміну від автора, який це практикує лише двічі на тиждень), називає їх «маніяками чистоти». Після ознайомлення приблизно $з$ двома третинами історії страждань від споглядання любителів зайвий раз протерти підлогу, автор вирішив поділитися також своїми «фаховими» спостереженнями щодо жінок-солдатів у контексті їхньої форми. Він згадує свої дитячі роки, коли 3 однолітками вони дуже шанували військову форму та хотіли вступити до війська. А далі заявляє, що з часу його юності підлітки навряд чи змінилися і не можуть серйозно сприймати «жіночі форми в уніформі». Згадує, що ще у роки Першої світової війни з членок тодішніх організацій при армії кепкували через їхне вбрання. А для характеристики сприйняття сучасним йому підростаючим поколінням жінок на службі у збройних силах не

\footnotetext{
${ }^{1}$ Women Take Up Arms // Portsmouth Evening News. 1939. 13 September. P. 1.

${ }^{2}$ «Key» Women of the War Achievements in 1939 // Hartlepool Northern Daily Mail. 1939. 19 December. P. 5.

${ }^{3}$ Наприклад, див. Maximum national effort // Hansard, the Official Report of debates in Parliament. 1941. Vol. 376. P. 1009-1095.
} 
без задоволення переповідає, як на його очах двоє маленьких дівчаток, що побачили британку у формі, перемовляючись між собою, констатували, що та жінка - не солдат, адже справжні солдати носять штани, які жінкам зовсім не личать. Ця ж пані, на їхню думку, просто хоче похизуватися перед громадськістю своїм подібним до військової форми вбранням ${ }^{4}$. Фактично повністю текст, що стосувався жінок у формі, через кілька днів переопублікувало на своїх шпальтах інше видання, вже під іншим авторством, хоча теж під псевдонімом ${ }^{5}$. А отже, подібні думки не були поодинокими і мали відгук у суспільстві.

Очевидною у 1940 р. була тенденція до збільшення кількості загальних матеріалів про жінок на різних видах служби у роки війни, зокрема і в інших країнах 6 . Це цілком закономірно, адже ворог посилював свої позиції й у суспільстві не було впевненості в успіхові країни у війні. Крім того, над нею нависла загроза окупації. За умови реалізації найгірших для Великої Британії сценаріїв цілком вірогідним було зняття наявної заборони на використання жінками зброї та допуск до бойових посад. Попри це у газетах переважали статті з критикою військовослужбовиць, особливо їхнього зовнішнього вигляду, а також ймовірності надання їм можливості виконувати бойові ролі. Так, стаття «Жінки у формі» («Women in Uniform»), опублікована наприкінці березня 1940 р., присвячена британкам на службі у Франції. У ній йшлося про те, що поряд з британськими військовослужбовцямичоловіками на вулицях Парижа поступово з'являються і жінки у формі. I парижани проходять повз них у цілковитій мовчанці, оскільки для них жінка у військовій формі - це цілковите відхилення від норми, яке тягне за собою втрату жіночності .

У газеті «Britannia and Eve» від 1 червня 1940 р. вийшов дуже великий матеріал, присвячений буцімто жінкам у формі, з аналогічною до попередньої статті назвою - «Жінки у формі» («Women in Uniform») ${ }^{8}$. Хоча насправді він не дуже пов'язаний з означеною темою. Його автор спершу розповідає про німкеню, яка дуже підтримувала нацистську ідеологію, i працювала поваркою в одному із закладів у Південній Африці. Вона навмисне погано готувала для американських і британських солдатів, у такий спосіб висловлюючи свою ненависть до них. Далі автор наводить фразу нацистів про те, що «деякі жінки можуть бути більш смертоносні за чоловіків». I, власне, наступні його розмірковування присвячені саме цьому. Автор наголошує, що всупереч назві матеріалу, йдеться не лише про жінок у військовій формі, а про жінок загалом, і їхній потенціал. Він стверджує, що у цю війну втягнуто більше жінок, ніж чоловіків, адже жіноче населення Франції, СРСР, Англії, Німеччини переважає над чоловічим, а війна має тотальний характер. I якщо жінки СРСР та Німеччини виховувалися їхніми урядами у ненависті до інших країн, й у франщузів також є країна, до якої вони десятиліттями ставляться вороже - Німеччина, то англійкам немає кого ненавидіти. Їхня єдина проблема у цій війні - знудженість. Саме через неї, на думку автора, вони ставали волонтерками численних організацій різного штибу.

Загалом він критикує жіночу службу в організаціях при збройних силах,

\footnotetext{
${ }^{4}$ Twixt you and me. Save us from the cult of tidiness: women soldiers more genteel to-day // Worthing Gazette. 1939. 29 November. P. 6.

${ }^{5}$ Women Soldiers // Littlehampton Gazette. 1939. 01 December. P. 4.

${ }^{6}$ Women Soldiers of France // Lancashire Evening Post. 1940. 11 June. P. 4.

${ }^{7}$ Women in Uniform // Motherwell Times. 1940. 29 March. P. 3.

${ }^{8}$ Women in Uniform // Britannia and Eve. 1940. 01 June. P. 68.
} 
посилаючись на чималу кількість статей про їхню непотрібність і нерентабельність, вказує на те, що медсестри роками працювали без непотрібних салютувань і маршів на плацу, що жінки у формі для декого є «найбільш сумною особливістю війни». Всі ці твердження, за словами автора, запозичені з листів до редакщії. I чимало з них були написані жінками. Тому, на його погляд, у них написана правда. Звісно, подібні твердження - лише погляд простого обивателя на проблему, сформований не внаслідок оперування реальними фактами, а під впливом стереотипних переконань про «справжнє жіноче покликання» і т.п. Адже, якби персонал жіночих організацій при збройних силах і справді був непотрібний і нерентабельний, уряд би не робив все можливе для залучення якомога більшої кількості жінок туди, і зрештою не оголосив їх призов наприкінці 1941 р. ${ }^{9}$

Не можна оминути і сексистське твердження автора про військову форму для жінок. Він, стверджуючи, що не хоче вступати у дискусію, чи добре виглядають жінки у формі, робить протилежне і починає дискутувати на тему їхньої непривабливості. Автор констатує, що якщо чоловік хоче зробити жінку непривабливою, йому варто дати їй армійський кашкет. А також висловлює щирий подив, чому б не укомплектувати їх головними уборами як у «гарненьких стюардес Американських авіаліній»? ${ }^{10}$

Водночас автор намагається передбачити і події повоєнних років, стверджуючи, що німкені після війни завершать свою еволюцію та повернуться до виховання дітей, француженки не захочуть нічого, крім успішного заміжжя, у радянських же є значний потенціал для контрреволюції, з огляду на їхню важку працю у колгоспах і поневіряння радянсько-фінської війни, внаслідок якої загинуло чимало їхніх чоловіків (радянськонімецька війна на момент виходу статті ще не почалася). А от англійки, які не піддавалися пропаганді (на думку автора), як росіянки та німкені, і не досягли тої задоволеності життям, що іï мають француженки, будуть еволюціонувати і надалі, і зрештою зможуть стати рівними партнерами чоловіків. Після цієї війни вони масово підуть у політику, і зможуть привнести щось нове. Тобто автор вважав, що Велика Британія стоїть на порозі суттєвих зрушень у соціальному укладі ${ }^{11}$. До слова, передбачуваної автором масової участі британок у політиці не відбулося, хоча після війни дійсно дещо збільшилася їх кількість серед обраних парламентарів. Однак до кінця 1980-х рр. вона не перевищувала позначки у 29 осіб (або 4,6\% від загальної кількості депутатів) ${ }^{12}$.

У статті, розміщеній у липневому номері «Belfast Telegraph», висловлено протест проти допущення жінок до бойових ролей. Пояснюючи свою позицію, авторка статті на ім'я Беатрис, спирається на традиційну вікторіанську модель розподілу ролей між чоловіком і жінкою. Вона згадує випадок, коли місіс Норман Кардвел роззброїла і взяла у полон німецького льотчика та підкреслює, наскільки це збентежило суспільство. Ця історія спонукала одну зі знайомих авторки засумніватися, чи дійсно ще не настав час дозволити жінкам бути солдатами. Беатрис визнає, що пропозиція дискусійна, адже багато жінок добре стріляють, є достатньо сильними, і вже стали на захист своїх країн у Фінляндії, Польщі чи Іспанії у роки громадянської війни. «Беззаперечно, - пише авторка, - що і

\footnotetext{
${ }^{9}$ Broad R. Conscription in Britain, 1939-1964: The Militarisation of a Generation. Taylor \& Francis, 2006. P. 137.

${ }^{10}$ Women in Uniform // Britannia and Eve. 1940. 01 June. P. 68.

${ }^{11}$ Ibid. P. 12-13, 68, 70.

${ }^{12}$ Women in the House of Commons. Factsheet M4 Members Series. London, 2010. P. 9.
} 
атлетичні, з активною громадянською позицією та ясним розумом британки є щонайменше такими ж хоробрими, як жінки цих країн. Я не 3 тих людей, які вважають, що життя чоловіка менш цінне чи менш необхідне для добробуту нації, ніж життя жінки, але наразі я не думаю, що це хороша ідея - мати навіть добровільну жіночу армію» ${ }^{13}$. Причиною цього, на думку авторки є той факт, що британці дуже прив'язані до своїх домівок, які вибудовуються навколо жінки. А функція чоловіка - захищати ї. Це така давня традиція, що авторка сумнівається, чи коли-небудь вона буде порушена. До того ж, жінки Великої Британії хоч і не воюють зі зброєю в руках, але та робота, що вони виконують у армії, ВПС, BMC, та невійськових організаціях і так є неоціненною. «Все це, - йдеться у статті, - може видаватися замалим і не принесе жінкам військових нагород, але поводитися інакше - це встромити чоловікам, що воюють, ніж у спину» ${ }^{14}$.

Кожна звістка про жінок, що служать зі зброєю у руках в інших країнах, викликала чимале збентеження у британському соціумі у перші роки війни. Так, суттєво вразила британців новина про те, що фіни збили радянський військовий літак, льотчицею якого виявилася вагітна жінка. Крім того, зазначалося, що у радянсько-фінській війні з боку СРСР жінки служили і водіями танків ${ }^{15}$.

Знаходилося місце для британок на службі й у публічному дискурсі зарубіжних високопоставлених гостей. Так, у своєму виступі прем'єр-міністр Австралії Р. Мензіс під час 10-тижневого візиту до Великої Британії навесні 1941 р. високо оцінив національну службу британок, зокрема у збройних силах. I продемонстрував неабияку відкритість i незашореність поглядів, адже фактично висловив сподівання на уклад, який багато в чому близький сучасному феміністичному руху. Він повторив вже звичну риторику про те, що йде народна війна, однак нагадав, що поняття «народ» включає і жінок. Про внесок останніх Р. Мензіс висловився так: «Я дякую Богу за таких людей. Вони - серед великих солдатів цієї війни. Наступне покоління британців можливо матиме матерів, які забули, як це непритомніти у часи кризи, які не чіплятимуться за чоловіків як той плющ за стіну, які нескромно вдягатимуть той жахливий одяг, який тривалий час вважався чоловічим, які не вважатимуть непоєднуваними помаду на обличчі та машинне масло на руках, які, як то кажуть, "змусять своїх вікторіанських бабусь перевертатися в могилах" - але вони будуть матерями справжніх чоловіків» ${ }^{16}$. На жаль, подібної позиції, яка б лунала 3 уст тогочасних британських політиків, нам відшукати не вдалося.

На тлі розмов про оголошення призову для британок і його умов у періодичних виданнях почастішали матеріали про практику залучення жінок до війська в інших країнах. Водночас не всі вони спиралися на достовірні факти. Так, у черговому номері газети «John Bull» від 16 серпня 1941 р. було розміщено великий матеріал про досвід СРСР в означеному питанні під назвою «Дівчата воюють у Червоній армії» («Girls are Fighting in the Red Armies») $)^{17}$. Проте правдиві факти у ньому подавалися разом з численними вигадками та домислами, які йдуть у розріз з даними сучасних досліджень. У матеріалі йшлося про

\footnotetext{
${ }^{13}$ Women Soldiers // Belfast Telegraph. 1940. 13 July. P. 6.

${ }^{14}$ Ibid. P. 6.

${ }^{15}$ Women Soldiers // Newcastle Journal. 1940. 29 February. P. 1.

${ }^{16}$ Britain's women great soldiers // Western Morning News. 1941. 05 May. P. 3; British Women Great Soldiers // Nottingham Journal. 1941. 05 May. P. 4; Our Women Great Soldiers // Western Mail. 1941. 05 May. P. 3.

${ }^{17}$ Girls are Fighting in the Red Armies // John Bull. 1941. 16 August. P. 9.
} 
радянських снайперок, цілі підрозділи, що складалися з жінок і керувалися ними, жінокартилеристок, які безперешкодно самі стріляли з гармат по ворогам, танкісток, зв'язківиць на фронті, операторок куль загородження, парашутисток-розвідниць. Й справді, радянські жінки впродовж війни дійсно могли служити на перелічених посадах. Однак, по-перше, дата виходу статті - 16 серпня 1941 р. Тобто радянсько-німецька війна тільки почалася і масштаби залучення жінок до армії ще не набули такого розмаху. По-друге, багато описаних у матеріалі деталей їхньої служби не відповідали реальному стану справ. Наприклад, у матеріалі зазначено, що станом на серпень 1941 р. у Червоній армії було приблизно 160 офіцерок на старших і молодших офіцерських посадах, з них щонайменше 5 генералок ${ }^{18}$. Останнє навряд чи відповідає дійсності. Адже в радянській армії дуже мало було жінок, що дослужилися до звання полковника. Відомостей про жінок-генералів нам відшукати не вдалося. Якщо подивитися список жінок-героїв Радянського Союзу, там не знайдеться жодної (!) генералки. Не менші сумніви викликає твердження про те, що станом на 1941 р. 750 тис. жінок вже служили на бойових посадах у Червоній армії ${ }^{19}$. Хоча наразі такі дані йдуть урозріз з більшістю сучасних підрахунків, за якими загальна чисельність жінок у Червоній армії становила від 800 тис. ${ }^{20}$ до 1 млн. ${ }^{21} €$ у цій статті й інші факти, достовірність яких сумнівна.

Досить значною була кількість загальних матеріалів, які стосувалися служби жінок у збройних силах, а також таких, які були дотичні до цієї теми й у 1942 р. Дуже показовим, на наш погляд, є наповнення окремих сторінок для жінок на службі. Воно неприкрито демонструвало суспільні очікування від британок у війську та формувало «прийнятне» для них коло інтересів. Так, більша частина інформації на такій сторінці у виданні «Reveille» 22 стосувалася рекомендацій для жінки на службі щодо слідкування за зовнішністю. Наприклад, цьому присвячені замітки: «Як доглядати за кучерями», «Волосся потрібно тримати в чистоті», «Як добре виглядати в уніформі». Також тут бачимо рекламу дезодоранту, пудри, помади, продуктів для підтримання «жіночої гігієни» тощо.

Крім того, на сторінці знаходимо невелику замітку про двох ветеранок Першої світової війни, які пішли служити до Допоміжної територіальної служби, та статтю про те, як стають офіцерками 3 добробуту у трьох допоміжних службах. Очевидно, що останній матеріал вийшов у світлі результатів звіту комісії Маркхем, де було зроблено висновок про те, що знайдені порушення у діяльності трьох жіночих служб багато в чому $є$ недопрацюванням 3 боку офіцерок 3 добробуту, які нібито недостатньо дбали про підлеглих ${ }^{23}$. У статті йдеться про те, що оперативних завдань такі офіцерки на службі не виконують, і їхнім основним обов'язком є керування підрозділом та ефективна організація його побуту і дозвілля. Описано тривалість їх підготовки, яка відрізнялася залежно від організації, а також особливості навчання ${ }^{24}$.

\footnotetext{
${ }^{18}$ Ibid. P. 9.

${ }^{19}$ Ibidem.

${ }^{20}$ Полторак С.Н. Женщины на фронтах Великой Отечественной войны. СПб., 2002. С. 21.

${ }^{21}$ Markwick R.D., Cardona E.Ch. Soviet Women on the Frontline in the Second World War. New York: Palgrave Macmillan, 2012. P. 1.

${ }^{22}$ The servicewoman's page // Reveille. 1942. 26 October. P. 7.

${ }^{23}$ Education and leadership in three women`s services // Nature. 1942. Vol. 150. P. 415.

${ }^{24}$ The servicewoman's page // Reveille. 1942. 26 October. P. 7.
} 
Привертає увагу також замітка «Вона знає всіх бойових асів», де йдеться про те, що робота клерка у Жіночих допоміжних повітряних силах може звучати непривабливо, однак має переваги у вигляді знайомства 3 найкращими льотчиками країни, а також високопосадовцями союзних сил. На нашу думку, статті з подібними заголовками та змістом мали на меті не лише привабити охочих подихати одним повітрям з тими, про кого пишуть у газетах, але й натякнути на можливе обростання клерків потрібними у житті зв'язками (хоча що це, як не потенційне поле для корупції у демократичному суспільстві, яке 3 нею люто боролося? - Aвт.), або й можливе заміжжя ${ }^{25}$. Тобто жінкам вкотре пропонували не дбати про свій власний розвиток і кар'єру, а знайти вигідну партію.

Поряд 3 матеріалами, які не виходили за межі «традиційних» гендерних ролей, траплялися й альтернативні статті, де висвітлювалася діяльність воячок. Однак щодо британок нам вдалося натрапити лише на матеріали історичного спрямування. Решта ж висвітлювали досвіди інших країн, насамперед, СРСР. Зокрема, у статті Е.Ярнхем «Британські жінки-солдати» («Britain’s Women Soldiers») ${ }^{26}$ йшлося про давнішні приклади участі жінок Великої Британії у збройних конфліктах зі зброєю в руках. Звісно, такий огляд мав на меті провести паралелі з поточним конфліктом, чого не заперечувала і сама авторка. Вона зазначила, що жінки Великої Британії наразі не виконують бойових ролей під час війни, на відміну від їхніх посестер у Росії (тобто СРСР), Польщі, Китаї, однак «немає сумнівів, що якби їх попросили, британки билися б з не меншою доблестю». Далі авторка подає короткий екскурс в історію, повідомляючи про випадки участі британок зі зброєю в руках у Трафальгарській битві (1805) - К. Доулінг, І. Бек і ще однієї, чиє ім'я невідоме; приклад Х. Уітні, яка служила у ВМС під час Семилітньої війни (1756-1761) й ін. Особливу увагу з боку авторки отримала К. Кавана, яка у XVII ст. пішла служити у військо через кохання. Ї̈̈ чоловіка, Т. Уолша, призвали до армії, і вона вирушила на його пошуки, але у процесі зрозуміла, що їй подобається бути воячкою. Також до особливо непересічних авторка статті віднесла приклад Ф. Хессел, яка у середині XVIII ст. служила рядовою 5-го пішого полку та побувала у різних куточках Європи. Жінка дожила до глибокої старості і померла у віці 108 років ${ }^{27}$.

Цікавим, на наш погляд, з точки зору гендерної оптики, є виклад матеріалу, що висвітлював візит у 1942 р. снайперки Л. Павличенко до Великої Британії: «...російська дівчина снайпер прибула до Лондона вчора у супроводі лейтенанта Червоної армії Пчелінца (насправді офіцера звали Володимир Пчелінцев - Aвт.) та молодіжного лідера Миколи Красавченка» ${ }^{28}$. Лише у другому абзаці зазначено, що і сама Л. Павличенко на той час була не просто «російською дівчиною» (до того ж, навіть не російською, а українською), а також офіцеркою радянської армії та мала таке саме звання, як і у офіцера-чоловіка, що ії супроводжував ${ }^{29}$.

Аналізуючи загальні матеріали щодо служби жінок у війську за 1943 р., мусимо констатувати збільшення кількості матеріалів, де категорично відкидалася можливість жінок виконувати бойові ролі. Так, П. Бентлі, яка позиціонувала себе борчинею за

\footnotetext{
${ }^{25}$ Ibid. P. 7.

${ }^{26}$ Yarnham E.R. Britain's Women Soldiers. Historical Characters of Past Campaigns // Britannia and Eve. 1942. 01 June. P. $18,70$.

${ }^{27}$ Ibid. P. $18,70$.

${ }^{28}$ Soviet Girl Sniper In Britain // Aberdeen Press and Journal. 1942. 06 November. P. 3.

${ }^{29}$ Ibid. P. 3.
} 
рівноправ'я і партнерство між статями та противницею війни, поставила собі за мету показати на шпальтах британських 3MI, чому жінки не мають бути рівними чоловікам у військовій сфері. Вона визнала, що «використання зброї іноді є правильним і необхідним» ${ }^{30}$ Однак воно суперечить жіночій природі: «е є суто жіночим покликанням - плекати, підживлювати, збагачувати життя. Вона робить це, коли виношує дитину; вона робить це, коли турбується про свою сімю. Коли вона заспокоює, втішає та надихає, вона виконує свою особливу функцію...» ${ }^{31}$. Через це для авторки сама думка про жінку, що йде знищувати життя, є огидною, протиприродною. I в цьому вона ідейно недалеко відійшла від своїх співвітчизників попередніх епох і збройних конфліктів, зокрема років Першої світової війни ${ }^{32}$. Також авторці не подобаються жінки, що займаються полюванням для розваги, а не для того, щоб вижити. I вона, як і чимало її співвітчизників, абсолютно не бачить різниці між реальним життям, де існують такі жінки, та власними переконаннями, які не можуть характеризувати нікого, за винятком їх власниці.

Водночас, відходом від звичної риторики попередніх років можна вважати переконання П. Бентлі про те, що єдиною формою бою, де білыш менш припустима участь жінок, - це та, яка відбувається в межах оборонних військових дій, а не наступальних, і для захисту не стільки себе, скільки дітей, підлітків, хворих та людей похилого віку. Авторка фактично намагається створити симбіоз вікторіанської моралі та сучасних їй воєнних реалій, поєднавши обов'язок самопожертви жінки заради оточення та необхідність відбивати атаки ворога наявними силами. Яскравим прикладом цього для П. Бентлі була служба жінок у ППО 33 .

У 1944 р. загалом поменшало матеріалів, присвячених проблемі жіночої служби. Періодично проскакували іронічні та відверто сексистські твердження щодо британок, які вже служили. Наприклад, у колонці «Те і се у Варвіку» в газеті «Warwick and Warwickshire Advertiser» від 15 вересня 1944 р. в одній із заміток членок Допоміжної територіальної служби названо «друзями чоловіка, i, звісно, солдата» ${ }^{34}$. В іншій читачів непокоїть питання щодо особливостей гендерного укладу після війни. Зокрема висловлено припущення, що британки, які обіймали відповідальні посади на заводах чи на військовій службі, не будуть покірними дружинами для своїх чоловіків ${ }^{35}$. Що, звісно, на той час вважалося вкрай негативним явищем. Щоб виправити становище, у 1944-1945 р. почали з'являтися матеріали, які висвітлювали «правильні» стратегії поведінки для жінок, зокрема на службі у

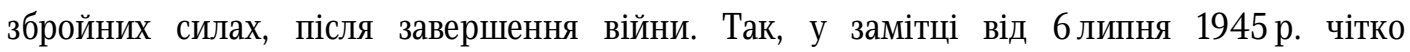
прослідковується намагання підкреслити другорядність служби членкині Жіночих королівських військово-морських сил щодо чоловічої: «вона приєдналася до Жіночої королівської військово-морської служби, щоб вивільнити чоловіка для служби на флоті» ${ }^{36}$. I

\footnotetext{
${ }^{30}$ Bentley P. Should women take up arms? // Newcastle Journal. 1943. 19 April. P. 2.

${ }^{31}$ Ibid. P. 2.

32 Залєток Н.В. Жінки в суспільному і політичному житті Великої Британії (друга половина ХІХ ст. - 1939 р.).

Київ: ПФ «Фоліант», 2017. С. 176.

${ }^{33}$ Bentley P. Should women take up arms? P. 2; Bentley P. Should women take up arms and fight? // Aberdeen Press and Journal. 1943. 22 April. P. 2.

${ }^{34}$ Love in the kitchen // Warwick and Warwickshire Advertiser. 1944. 15 September. P. 3.

${ }^{35}$ A woman's weapon // Warwick and Warwickshire Advertiser. 1944. 15 September. P. 3.

${ }^{36}$ Homes for husbands, say married WRENS // Shepton Mallet Journal. 1945. 06 July. P. 2.
} 
нагадати про «справжнє призначення» жінки, адже тепер «...вона попрощалась зі своєю військовою службою, щоб створювати затишок для її чоловіка-інженера» ${ }^{37}$.

Таким чином, проблема служби жінок у збройних силах як явище займала досить вагоме місце у суспільному дискурсі у 1939-1945 pp. У британській періодиці зазначеного періоду була оприлюднена низка матеріалів, в яких містилася оцінка широкого спектру заходів, пов'язаних із залученням британок до служби у війську, порушувалися питання про засади, на яких могли служити жінки тощо. Мусимо констатувати, що у представлених публікаціях містилася низка критичних висловлювань щодо жіночої служби, особливо це стосувалося можливості виконання ними бойових ролей. Вельми значна увага у контексті обговорення служби британок приділялася не питанням, пов'язаним з їхньою фаховістю, а зовнішньому вигляду, особливостям форми, яка, на думку деяких, не була «жіночною», проблемам, які потенційно можуть виникнути через те, що успіхи британок на службі у збройних силах стануть перешкодою майбутньому заміжжю, адже самодостатні жінки навряд чи будуть покірними тощо.

\title{
Nataliia Zalietok
}

\section{The problem of women's service in the armed forces in the British public discourse 1939-1945 (on the materials of periodicals)}

\begin{abstract}
World War II became such a large-scale armed conflict in human history that many of the countries involved in it were forced to reconsider their policies to enlist women in the army. Great Britain, despite its rather conservative reputation in the field of gender policy, officially began to recruit women to serve in women's auxiliary organizations during the First World War. In 1939-1945, it significantly expanded the scope of women's involvement in the armed forces, as well as the list of positions available to them. The purpose of this article is to analyse the peculiarities of the perception of British society in 1939-1945 of a phenomenon of women's service in the armed forces. The source base of the study is the materials of British periodicals. In general, the problem of women's service in the armed forces as a phenomenon occupied a very important place in public discourse on 1939-1945. In the British periodicals of this period, a number of materials were published, which addressed to a wide range of measures related to the enlistment of British women in the army, raised questions about the principles on which women could serve, and so on. It should be noted that the analysed publications contained a number of critical statements about women's service, especially with regard to their ability to perform combat roles. In the context of discussing the service of British women, the attention was paid not to their professionalism, but to the issues of their appearance, «unfeminine» uniform, problems that could potentially arise due to their success on the service, which will be an obstacle to future marriage, because self-sufficient women are unlikely to be submissive, and so on.
\end{abstract}

Keywords: women, armed forces, World War II, Great Britain, women's auxiliary organizations, public discourse

${ }^{37}$ Ibid. P. 2. 